Pacific Journal of Mathematics

A NOTE ON CERTAIN DUAL SERIES EQUATIONS INVOLVING

LAGCURRE POLIS EQUALS 


\title{
A NOTE ON CERTAIN DUAL SERIES EQUATIONS INVOLVING LAGUERRE POLYNOMIALS
}

\author{
H. M. SRivastava
}

In this paper an exact solution is obtained for the dual series equations

$$
\begin{array}{ll}
\sum_{n=0}^{\infty} \frac{A_{n}}{\Gamma(\alpha+n+1)} L_{n}^{(\alpha)}(x)=f(x), & 0 \leqq x<y, \\
\sum_{n=0}^{\infty} \frac{A_{n}}{\Gamma(\alpha+\beta+n)} L_{n}^{(\sigma)}(x)=g(x), & y<x<\infty,
\end{array}
$$

where $\alpha+\beta+1>\beta>1-m, \sigma+1>\alpha+\beta>0, m$ is a positive integer,

$$
L_{n}^{(\alpha)}(x)=\left(\begin{array}{c}
\alpha+n \\
n
\end{array}\right){ }_{1} F_{1}[-n ; \alpha+1 ; x],
$$

is the Laguerre polynomial and $f(x)$ and $g(x)$ are prescribed functions.

The method used is a generalization of the multiplying factor technique employed by Lowndes [4] to solve a special case of the above equations when

$$
\sigma=\alpha, A_{n}=\Gamma(\alpha+n+1) \Gamma(\alpha+\beta+n) C_{n}, \alpha+\beta>0 \text { and } 1>\beta>0 .
$$

In another paper by the present author [5] equations (1) and (2) have been solved by considering separately the equations when (i) $g(x) \equiv 0$, (ii) $f(x) \equiv 0$, and reducing the problem in each case to that of solving an Abel integral equation. Indeed it is easy to verify that the solution obtained earlier [5] is in complete agreement with the one given in this paper.

2. The following results will be required in the analysis.

(i) The orthogonality relation for Laguerre polynomials given by [3, p. $292(2)]$ and [3, p. $293(3)]$ :

$$
\int_{0}^{\infty} e^{-x} x^{\alpha} L_{m}^{(\alpha)}(x) L_{n}^{(\alpha)}(x) d x=\frac{\Gamma(\alpha+n+1)}{n !} \delta_{m n}, \alpha>-1,
$$

where $\delta_{m n}$ is the Kronecker delta.

(ii) The formula (27), p. 190 of [2] in the form:

$$
\frac{d^{m}}{d x^{m}}\left\{x^{\alpha+m} L_{n}^{(\alpha+m)}(x)\right\}=\frac{\Gamma(\alpha+m+n+1)}{\Gamma(\alpha+n+1)} x^{\alpha} L_{n}^{(\alpha)}(x) .
$$

(iii) The following forms of the known integrals [2, p. 191 (30)] and [3, p. $405(20)]$ : 
(5)

$$
\int_{0}^{\xi} x^{\alpha}(\xi-x)^{\beta-1} L_{n}^{(\alpha)}(x) d x=\frac{\Gamma(\alpha+n+1) \Gamma(\beta)}{\Gamma(\alpha+\beta+n+1)} \xi^{\alpha+\beta} L_{n}^{(\alpha+\beta)}(\xi),
$$

where $\alpha>-1, \beta>0$, and

$$
\int_{\xi}^{\infty} e^{-x}(x-\xi)^{\beta-1} L_{n}^{(\alpha)}(x) d x=\Gamma(\beta) e^{-\xi} L_{n}^{(\alpha-\beta)}(\xi),
$$

where $\alpha+1>\beta>0$.

3. Solution of the equations. Multiplying equation (1) by $x^{\alpha}(\xi-x)^{\beta+m-2}$, where $m$ is a positive integer, equation (2) by $e^{-x}(x-\xi)^{\sigma-\alpha-\beta}$, and integrating with respect to $x$ over $(0, \xi),(\xi, \infty)$ respectively we find, on using (5) and (6), that

$$
\begin{aligned}
& \sum_{n=0}^{\infty} \frac{A_{n}}{\Gamma(\alpha+\beta+m+n)} L_{n}^{(\alpha+\beta+m-1)}(\xi) \\
& \quad=\frac{\xi^{-\alpha-\beta-m+1}}{\Gamma(\beta+m-1)} \int_{0}^{\xi} x^{\alpha}(\xi-x)^{\beta+m-2} f(x) d x,
\end{aligned}
$$

where $0<\xi<y, \alpha>-1, \beta+m>1$, and

$$
\begin{aligned}
\sum_{n=0}^{\infty} & \frac{A_{n}}{\Gamma(\alpha+\beta+n)} L_{n}^{(\alpha+\beta-1)}(\xi) \\
& =\frac{e^{\xi}}{\Gamma(\sigma-\alpha-\beta+1)} \int_{\xi}^{\infty} e^{-x}(x-\xi)^{\sigma-\alpha-\beta} g(x) d x,
\end{aligned}
$$

where $y<\xi<\infty, \sigma+1>\alpha+\beta>0$.

If we now multiply equation (7) by $\xi^{\alpha+\beta+m-1}$, differentiate both sides $m$ times with respect to $\xi$ and use the formula (4) we see that it becomes

$$
\begin{aligned}
& \sum_{n=0}^{\infty} \frac{A_{n}}{\Gamma(\alpha+\beta+n)} L_{n}^{(\alpha+\beta-1)}(\xi) \\
& \quad=\frac{\xi^{-\alpha-\beta+1}}{\Gamma(\beta+m-1)} \frac{d^{m}}{d \xi^{m}} \int_{0}^{\xi} x^{\alpha}(\xi-x)^{\beta+m-2} f(x) d x,
\end{aligned}
$$

where $0<\xi<y, \alpha\rangle-1$, and $\beta+m>1$.

The left-hand sides of equations (8) and (9) are now identical and an application of the orthogonality relation (3) yields the solution of equations (1) and (2) in the form

$$
\begin{aligned}
A_{n}= & \frac{n !}{\Gamma(\beta+m-1)} \int_{0}^{y} e^{-\xi} L_{n}^{(\alpha+\beta-1)}(\xi) F(\xi) d \xi \\
& +\frac{n !}{\Gamma(\sigma-\alpha-\beta+1)} \int_{y}^{\infty} \xi^{\alpha+\beta-1} L_{n}^{(\alpha+\beta-1)}(\xi) G(\xi) d \xi, \\
& n=0,1,2,3, \cdots,
\end{aligned}
$$


where

$$
F(\xi)=\frac{d^{m}}{d \xi^{m}} \int_{0}^{\xi} x^{\alpha}(\xi-x)^{\beta+m-2} f(x) d x
$$

and

$$
G(\xi)=\int_{\xi}^{\infty} e^{-x}(x-\xi)^{\sigma-\alpha-\beta} g(x) d x
$$

provided that $\alpha+\beta+1>1-m$ and $\sigma+1>\alpha+\beta>0, m$ being a positive integer.

When $\sigma=\alpha, A_{n}=\Gamma(\alpha+n+1) \Gamma(\alpha+\beta+n) C_{n}$, the above equations provide the solution to Lowndes' equations for

$$
\alpha+\beta>0,1>\beta>1-m,
$$

and when $m=1$ the results are in complete agreement (see [4], p. 124). Note also that the dual equations considered recently by Askey [1, p. 683, Th. 3] are essentially the same as Lowndes' equations.

The author should like to express his thanks to the referee for suggesting a number of improvements in the original version of the paper.

\section{REFERENCES}

1. Richard Askey, Dual equations and classical orthogonal polynomials, J. Math. Anal. Appl. 24 (1968), 677-685.

2. A. Erdélyi, W. Magnus, F. Oberhettinger and F. G. Tricomi, Higher Transcendental functions, Vol. II, McGraw-Hill, New York, 1953.

3. A. Erdélyi, W. Magnus, F. Oberhettinger and F. G. Tricomi, Tables of integral transforms, Vol. II, McGraw-Hill, New York, 1954.

4. John S. Lowndes, Some dual series equations involving Laguerre polynomials, Pacific

J. Math. 25 (1968), 123-127.

5. H. M. Srivastava, Dual series relations involving generalized Laguerre polynomials, Notices Amer. Math. Soc. 16 (1969), 568. (See also p. 517.)

Received January 20, 1969.

WEST VIRGINIA UNIVERSity

MORGantown, WeSt VIRGINIA 



\title{
PACIFIC JOURNAL OF MATHEMATICS
}

\author{
EDITORS
}

H. ROYDEN

Stanford University

Stanford, California

R. R. PhelPS

University of Washington

Seattle, Washington 98105
J. DUGUNDJI

Department of Mathematics

University of Southern California

Los Angeles, California 90007

RICHARD ARENS

University of California

Los Angeles, California 90024

\section{ASSOCIATE EDITORS}
E. F. BECKENBACH
B. H. NeumanN
F. WOLF
K. YoSHIDA

\section{SUPPORTING INSTITUTIONS}

\author{
UNIVERSITY OF BRITISH COLUMBIA \\ CALIFORNIA INSTITUTE OF TECHNOLOGY \\ UNIVERSITY OF CALIFORNIA \\ MONTANA STATE UNIVERSITY \\ UNIVERSITY OF NEVADA \\ NEW MEXICO STATE UNIVERSITY \\ OREGON STATE UNIVERSITY \\ UNIVERSITY OF OREGON \\ OSAKA UNIVERSITY \\ UNIVERSITY OF SOUTHERN CALIFORNIA
}

\author{
STANFORD UNIVERSITY \\ UNIVERSITY OF TOKYO \\ UNIVERSITY OF UTAH \\ WASHINGTON STATE UNIVERSITY \\ UNIVERSITY OF WASHINGTON \\ $\stackrel{*}{*} \stackrel{*}{*}{ }^{*}{ }^{*}$ \\ CHEVRON RESEARCH CORPORATION \\ TRW SYSTEMS \\ NAVAL WEAPONS CENTER
}

The Supporting Institutions listed above contribute to the cost of publication of this Journal, but they are not owners or publishers and have no responsibility for its content or policies.

Mathematical papers intended for publication in the Pacific Journal of Mathematics should be in typed form or offset-reproduced, double spaced with large margins. Underline Greek letters in red, German in green, and script in blue. The first paragraph or two must be capable of being used separately as a synopsis of the entire paper. It should not contain references to the bibliography. Manuscripts, in duplicate if possible, may be sent to any one of the four editors. Please classify according to the scheme of Math. Rev. 36, 1539-1546. All other communications to the editors should be addressed to the managing editor, Richard Arens, University of California, Los Angeles, California, 90024.

50 reprints are provided free for each article; additional copies may be obtained at cost in multiples of 50 .

The Pacific Journal of Mathematics is published monthly. Effective with Volume 16 the price per volume (3 numbers) is $\$ 8.00$; single issues, $\$ 3.00$. Special price for current issues to individual faculty members of supporting institutions and to individual members of the American Mathematical Society: $\$ 4.00$ per volume; single issues $\$ 1.50$. Back numbers are available.

Subscriptions, orders for back numbers, and changes of address should be sent to Pacific Journal of Mathematics, 103 Highland Boulevard, Berkeley, California, 94708.

PUBLISHED BY PACIFIC JOURNAL OF MATHEMATICS, A NON-PROFIT CORPORATION

Printed at Kokusai Bunken Insatsusha (International Academic Printing Co., Ltd.), 7-17, Fujimi 2-chome, Chiyoda-ku, Tokyo, Japan. 


\section{Pacific Journal of Mathematics \\ Vol. 30, No. $2 \quad$ October, 1969}

Gregory Frank Bachelis, Homomorphisms of annihilator Banach algebras.

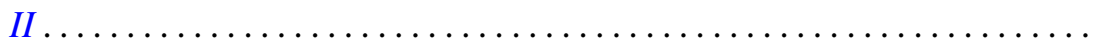

Leon Bernstein and Helmut Hasse, An explicit formula for the units of an algebraic number field of degree $n \geq 2 \ldots \ldots \ldots \ldots \ldots \ldots \ldots . \ldots 29$

David W. Boyd, Best constants in a class of integral inequalities ........ 367

Paul F. Conrad and John Dauns, An embedding theorem for lattice-ordered

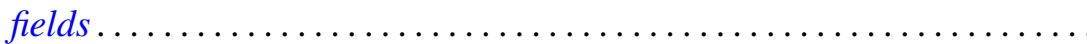

H. P. Dikshit, Summability of Fourier series by triangular matrix

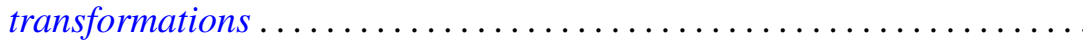

Dragomir Z. Djokovic, Linear transformations of tensor products preserving a fixed rank............................. 411

John J. F. Fournier, Extensions of a Fourier multiplier theorem of Paley . . . 415 Robert Paul Kopp, A subcollection of algebras in a collection of Banach

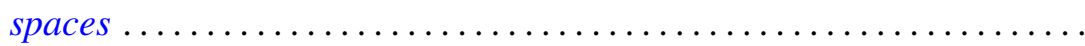

Lawrence Louis Larmore, Twisted cohomology and enumeration of vector bundles ...................................... 437

William Grenfell Leavitt and Yu-Lee Lee, A radical coinciding with the lower radical in associative and alternative rings .................

Samuel Merrill and Nand Lal, Characterization of certain invariant subspaces of $H^{p}$ and $L^{p}$ spaces derived from logmodular

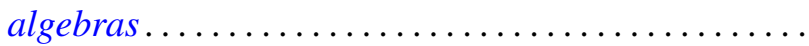

Sam Bernard Nadler, Jr., Multi-valued contraction mappings ....

T. V. Panchapagesan, Semi-groups of scalar type operators in Banach spaces ....................................

J. W. Spellmann, Concerning the infinite differentiability of semigroup motions

H. M. (Hari Mohan) Srivastava, A note on certain dual series equations involving Laguerre polynomials.

Ernest Lester Stitzinger, A nonimbedding theorem of associative algebras................................

J. Jerry Uhl, Jr., Martingales of vector valued set functions ...

John Mays Worrell Jr., On continuous mappings of metacompact $\check{C} e c h$

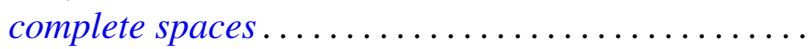

